\title{
Morphological and Ecological Variation among Populations and Subspecies of Burbot (Lota lota [L, 1758]) from the Mackenzie River Delta, Canada
}

\author{
Hans Recknagel ${ }^{1}$, Amy Amos ${ }^{2,3}$, and Kathryn R. Elmer ${ }^{1}$ \\ ${ }^{1}$ Institute of Biodiversity, Animal Health \& Comparative Medicine, College of Medical, Veterinary \& Life Sciences, University \\ of Glasgow, Glasgow G12 8QQ United Kingdom \\ ${ }^{2}$ Gwich'in Renewable Resources Board, PO Box 2240, Inuvik, Northwest Territories X0E 0T0 Canada \\ ${ }^{3}$ Corresponding author: aamos@grrb.nt.ca
}

Recknagel, Hans, Amy Amos, and Kathryn R. Elmer. 2014. Morphological and ecological variation among populations and subspecies of Burbot (Lota lota [L, 1758]) from the Mackenzie River Delta, Canada. Canadian Field-Naturalist 128(4): 377-384.

The Burbot (Lota lota [L, 1758]) is a holarctic distributed freshwater fish in the Gadidae family. In northwestern Canada, it has an important value for local and traditional fisheries. We describe the morphology and ecology of Burbot from four populations in the Mackenzie River Delta. Two subspecies come into contact in this area, which is the western edge of Lota lota maculosa distribution (one population in our study) and the eastern edge of Lota lota lota distribution (three populations in our study). We found the combined length-weight relationship in these four populations to be $\log _{10}$ (weight) $=-3.986+2.617 * \log _{10}$ (length). There was no difference in mean body length (overall mean and standard deviation $73.4 \pm 8.7 \mathrm{~cm}$ ), although the $L$. l. lota populations were heavier than the L. l. maculosa population. All populations differed in their carbon and nitrogen stable isotope signatures $\left(\delta^{15} \mathrm{~N}\right.$ overall mean $12.1 \pm 1.59 ; \delta^{13} \mathrm{C}$ overall mean $\left.-25.54 \pm 1.11\right)$. Main prey items were four fish species: Ninespine Stickleback (Pungitius pungitius [L, 1758]), Broad Whitefish (Coregonus nasus [Pallas, 1776]), Burbot, and Northern Pike (Esox lucius [L, 1758]). Ecological and morphological differences may be due to local conditions and population variability or to the different Lota lota subspecies. More ecological and morphological information from this region is needed to resolve possible phenotypic differences between the subspecies.

Key Words: Burbot; Lota lota; Mackenzie River; weight-length relationship; sexual dimorphism; ecological variation; parapatric subspecies; freshwater fish; loche

\section{Introduction}

The Burbot (Lota lota $[\mathrm{L}, 1758])$ is a northern fish species with a circumpolar distribution in freshwater rivers, creeks, and lakes. Burbot live in cold lakes and rivers, where they tend to frequent deep water near the bottom (McPhail and Paragamian 2000). They can attain a length of $1 \mathrm{~m}$ and a weight of $8 \mathrm{~kg}$, although most fish are $0.3-0.6 \mathrm{~m}$ in length and weigh $1-3 \mathrm{~kg}$ (McPhail and Paragamian 2000). The Mackenzie River Delta (Northwest Territories, Canada) is one of the northernmost ranges of Burbot distribution. In this area, they are fished for their liver and eggs, which are their most valued parts (Gwich'in Elders 1999). Recently, there have been increased reports of Burbot with malformations, poor muscle tone, unpleasant tasting flesh, and diseased livers from local and traditional fishers in the Gwich'in Settlement Area (Thompson 2008). This prompted research by the Gwich'in Renewable Resources Board, the data from which are the basis of this study.

Burbot are great dispersers and individuals may cover extensive geographic areas, perhaps driven by spawning behaviour and the search for food (McPhail and Paragamian 2000; Slavík et al. 2005). Their spawning period ranges from winter (December) until early spring (March), when water is often still covered by ice (Gwich'in Elders 1999; McPhail and Paragamian 2000).
Little is known about spawning behaviour in nature, but it seems to be polygynous broadcast spawning, as Burbot form spawning aggregations where a few females are surrounded by many males (McCrimmon 1959). There is no evidence of sex-biased dispersal based on population genetic analyses (Elmer et al. 2012). Whether Burbot have defined home ranges depends on their habitat. In lakes, Burbot do not keep stable positions as food availability is low and dispersed, whereas, in rivers, higher food availability permits them to occupy defined home ranges (Slavík et al. 2005). Burbot home ranges are much bigger than those of other temperate freshwater fish, with measured movements of up to $255 \mathrm{~km}$ (McPhail and Paragamian 2000).

There are two subspecies of Burbot: Lota lota maculosa is restricted to North America and Lota lota lota is distributed across Eurasia and Beringia. Based on population genetic analyses, Elmer et al. (2012) located a precise contact zone between Burbot subspecies in the Mackenzie River Delta. At Tsiigehtchic (included in the current study), most individuals collected were L. l. maculosa and upriver of that locality only $L$. $l$. maculosa were found. Downstream from Tsiigehtchic, all populations in the Mackenzie River Delta were exclusively L. l. lota. Therefore, the lower Mackenzie River is where the discrete parapatric distributions of 
the Burbot subspecies meet at a narrow contact zone and there is very little hybridization.

Some biologists consider the two subspecies to be morphologically variable. The subspecies may differ in caudal-peduncle ratio, the size of the pectoral fins, and the number of pyloric caeca (e.g., Pivnicka 1970; McPhail and Paragamian 2000), but some authors (e.g., McPhail and Lindsey 1970; Scott and Crossman 1973) have declined to distinguish subspecies because supposedly diagnostic traits are highly variable. Weight is thought to differ between fish from lentic and lotic environments and possibly between the two subspecies as well (Fisher et al. 1996). The causes for this morphological variation are not clear (McPhail 1997). To some extent, the variation might be a result of repeated isolation in refugia during multiple glacial cycles, which led to different genetic lineages and even subspecies (Van Houdt et al. 2005; Elmer et al. 2008). Morphological differences between fluvial and lacustrine Burbot have also been observed and led to the conclusion that lotic and lentic morphologies may be adapted to alternative contemporary niches (McPhail 1997). To date, there is a dearth of information about the morphological, meristic, and ecological variability of this wide-ranging species and, unfortunately, much of it is only available in grey literature (e.g., McPhail 1997; although see recent research advances by Cott et al. 2013a,b).

In this study, we describe and compare aspects of ecological differentiation and morphological variability among Burbot populations in the Mackenzie River Delta. As the two subspecies abut in this zone (Elmer et al. 2008, 2012) and there is little or no information available about possible ecological and reproductive barriers between subspecies (McPhail 1997), our aim was to assess variability in body size and weight, gonadosomatic index, and ecology (trophic niche and diet) and highlight possible areas for future research.

\section{Study Area}

Burbot were caught during winter 2007 and 2008 by line hooking at four traditional Burbot fishing locations in the Mackenzie River Delta by Gwich'in community fish monitors (Table 1, Figure 1). In Inuvik, two localities were fished: at Bombadeer Creek downstream from a sewage lagoon and at Sam Arey's Creek just upstream. In Aklavik, all fish were collected from Jackfish Creek, across from town. In Tsiigehtchic, Burbot were mostly collected from the Arctic Red River but some were captured from the Mackenzie River within $10 \mathrm{~km}$ of Tsiigehtchic. For Fort McPherson, all locations were Peel River tributary creeks (Woody Elias Creek, Basook Creek, Nelson Creek, Husky River Creek, Hudson Bay Creek, Rotten Eye Creek) within $50 \mathrm{~km}$ of Fort McPherson.

\section{Methods}

Total length was measured to the nearest millimetre. Wet weight of each fish was taken to the nearest gram. Stomachs were weighed and examined for species of macrofauna by a Gwich' in Renewable Resources Board technician. Gonads were extracted and weighed for fecundity analysis using the gonadosomatic index (GSI $=[$ gonad weight $/$ body weight $] \times 100)$. Fish ages were inferred from otoliths by A.A. in 2007 and under contract by North/South Consultants Inc. in 2008. A muscle tissue sample was collected and stable isotope measurements were taken by Environment Canada using mass spectrometry.

\section{Statistical analyses}

We tested whether morphological (weight and length) and ecological characteristics (stable isotopes, stomach content) differed among populations using analysis of covariance (ANCOVA) with age and sex as covariates to correct for age-specific differences and sexual dimorphism. Stomach content data were first transformed into a contingency table and then analyzed using a generalized linear model and a $\chi^{2}$ test with prey type as a covariate. In case a characteristic differed significantly among populations, all populations were contrasted using generalized linear models, setting sex and age as fixed effects as they are likely to influence morphological and ecological characteristics (i.e., older fish are usually larger, diet may shift during ontogeny, etc.) to determine which populations differed from each other. In these pairwise population comparisons, we corrected for multiple testing by using the Bonferroni correction. We conducted statistical analyses in $\mathrm{R}$ version 3.0.2 open-source programming language. We pooled individual data by population to compare means and standard deviations. We calculated weight-length relationships using weight in grams and length in milli-

TABLE 1. Sampling location and dates for Burbot subspecies (Lota lota lota and L. l. maculosa) collected from four populations in the Mackenzie River Delta, Northwest Territories, Canada.

\begin{tabular}{lrccl}
\hline \hline Population* & $n$ & Latitude, ${ }^{\circ} \mathrm{N}$ & Longitude, $^{\circ} \mathrm{W}$ & \\
\hline Lota lota lota & & & & Collection dates \\
Inuvik & 94 & 68.4 & 133.9 & Feb. and May 2007, Jan. and Feb. 2008 \\
Aklavik & 133 & 68.3 & 134.9 & Nov. 2007, Jan. 2008 \\
Fort McPherson & 137 & 67.7 & 134.7 & Nov. 2007, Feb. 2008 \\
Lota lota maculosa & 28 & 67.4 & 133.8 & Nov. 2007 \\
Tsiigehtchic & & & & \\
\hline \hline
\end{tabular}

\footnotetext{
*Subspecies inferred from Elmer et al. (2012).
} 


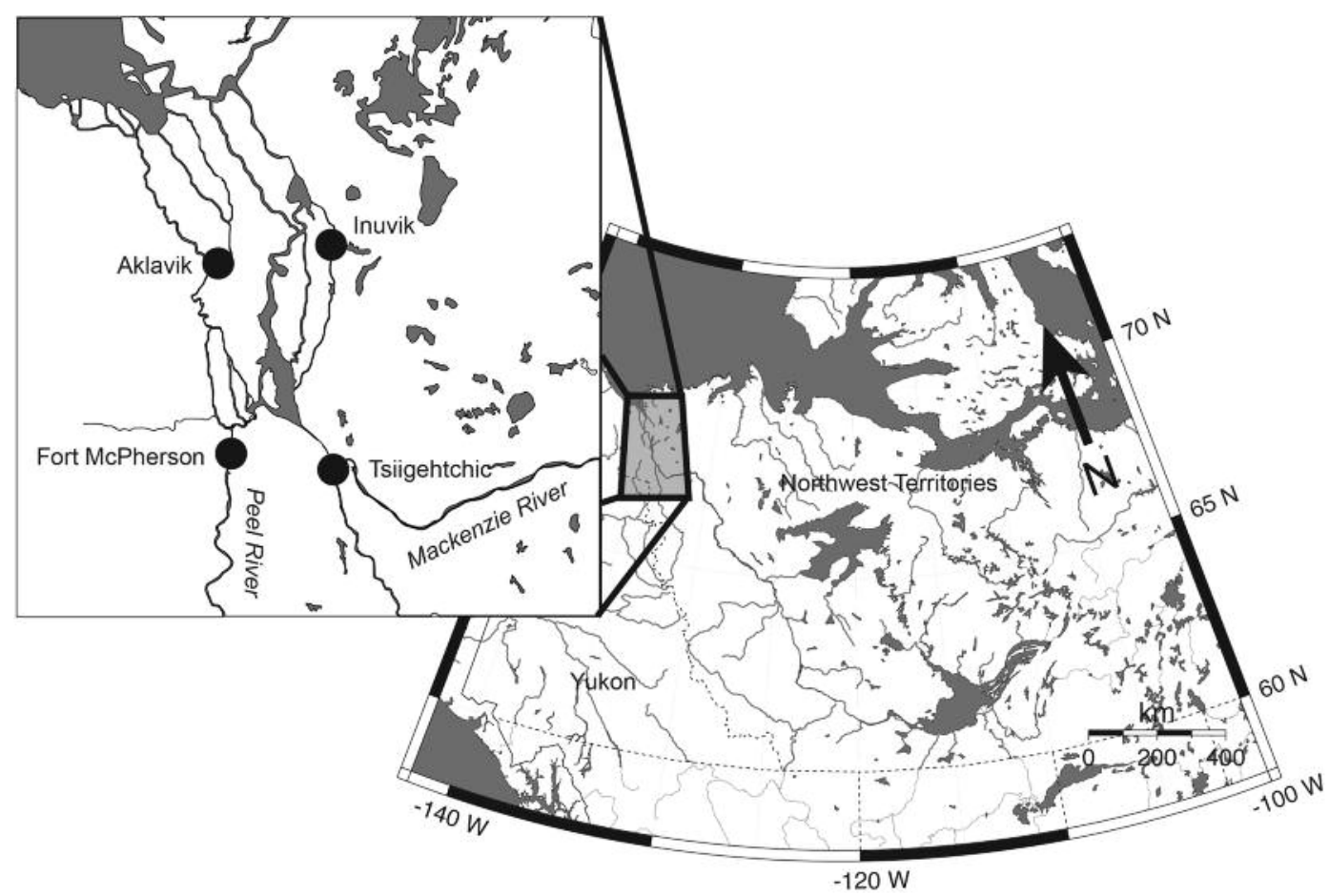

FiguRE 1. Sampling locations (black dots) for Burbot subspecies (Lota lota lota and L. l. maculosa) in the Mackenzie River Delta, Northwest Territories, Canada.

metres across all populations (following Fisher et al. 1996). We compared GSI for the two sexes using ANOVA.

\section{Results}

Age

The individuals in our samples were mostly older adults (mean age 13.6 years) (Table 2). Mean ages were approximately equal across populations, except for the Tsiigehtchic population, which was older (mean 14.9 years, range $9-25$ years, $F=3.559, P=0.0176$; Table 2 ). The age difference was significant only between the Fort McPherson and Tsiigehtchic populations $(t=$ $3.221, P=0.0018)$. Therefore, our ecological and morphological analyses are unlikely to be influenced by varying age effects across populations; however, we performed subsequent statistical analyses with age as a covariate.

\section{Sexual dimorphism}

Across all populations, female and male Burbot differed significantly in weight and length, females being longer (mean [ \pm standard deviation] $757 \pm 82 \mathrm{~mm}$ versus $683.4 \pm 72 \mathrm{~mm}, F=10.15, P=0.002)$ and heavier (mean $3699 \pm 1240 \mathrm{~g}$ versus $2785 \pm 891 \mathrm{~g}, F=13.16$, $P=0.0005)$ than males. Diet did not differ significant- ly between the sexes, as indicated by stomach contents $(F=3.82, P=0.35)$ and stable isotope $\left(\delta^{15} \mathrm{~N}: F=1.65\right.$, $\left.P=0.20 ; \delta^{13} \mathrm{C}: F=0.24, P=0.63\right)$ analyses. Mean GSI differed significantly between the sexes $(F=303.69$, $P<0.0001)$, and was on average $5.66 \pm 1.58(n=245)$ for mature females and 11.26 $\pm 4.26(n=84)$ for mature males (Table 2).

\section{Morphological variation across populations}

Body length differed significantly across populations $(F=10.51, P<0.0001)$. Mean length was less in the Tsiigehtchic population $(707.5 \pm 73.8 \mathrm{~mm})$ compared with the other three populations (Aklavik 731.3 $\pm 78.0 \mathrm{~mm}$, Fort McPherson $726.5 \pm 97.3 \mathrm{~mm}$, Inuvik $748.7 \pm 86.3 \mathrm{~mm})$, but only Fort McPherson and Aklavik $(t=-3.762, P=0.0003)$ and Inuvik and Fort McPherson $(t=-3.428, P=0.0009)$ differed significantly from each other after Bonferroni correction (Tables 2 and 3 ).

Weight differed significantly between populations $(F=20.37, P<0.0001)$ and ranged from $2471.0 \pm$ $829.2 \mathrm{~g}$ in Tsiigehtchic up to $3523.9 \pm 1304.0 \mathrm{~g}$ in Inuvik (Table 2). The Tsiigehtchic population had the lowest mean weight and, overall, three of the six pairwise comparisons of weight were significantly different (Table 3). 
Across populations and sexes combined, the lengthweight relationship was $\log _{10}$ (weight) $=-3.986+2.617$ * $\log _{10}$ (length). For subspecies L. l. lota (i.e., Burbot from Inuvik, Aklavik, and Fort McPherson populations) the length-weight relationship was $\log _{10}$ (weight) = $-3.882+2.583 * \log _{10}($ length $)(n=311)$. For subspecies L. l. maculosa (i.e., Burbot from the Tsiigehtchic population) the length-weight relationship was $\log _{10}$ $($ weight $)=-5.458+3.102 * \log _{10}($ length $)(n=27)$.

\section{Ecological variation across populations}

The mean $\delta^{15} \mathrm{~N}$ in the four Burbot populations ranged from $11.33 \pm 1.21$ to $13.43 \pm 1.32$. Values of $\delta^{13} \mathrm{C}$ ranged from $-24.49 \pm 0.87$ to $-26.03 \pm 1.05$ (Table 2). Populations differed significantly in stable isotope composition, for both $\delta^{13} \mathrm{C}$ and $\delta^{15} \mathrm{~N}$ (Table 3, Figure 2). Populations from Inuvik and Fort McPherson differed most, both in $\delta^{15} \mathrm{~N}(P<0.001)$ and $\delta^{13} \mathrm{C}$ values $(P<0.001)$ (Table 3$)$. Northern populations tended to differ significantly in their $\delta^{15} \mathrm{~N}$ isotope composition when compared to southern populations (Fort McPherson versus Aklavik: $P=0.013$, Inuvik versus Fort McPherson: $P<0.0001$, Tsiigehtchic versus Inuvik: $P=0.002)$ except for the populations Tsiigehtchic versus Aklavik $(P=0.176)$, although Fort McPherson versus Aklavik was not statistically significant after Bonferroni correction at $\alpha=0.05(P>0.0083)$. Comparisons of $\delta^{15} \mathrm{~N}$ isotope composition within the two northern populations (Inuvik-Aklavik) and the two southern populations (Tsiigehtchic-Fort McPherson) were not significantly different. The opposite was the case for $\delta^{13} \mathrm{C}$ isotope composition, where most populations differed significantly, except for two comparisons between north and south populations (Fort McPherson-Aklavik and Tsiigehtchic-Inuvik, the latter not significantly after Bonferroni correction).

Stomach contents of Burbot consisted mainly of four fish species: Ninespine Stickleback (Pungitius pungitius [L, 1758]), Broad Whitefish (Coregonus nasus [Pallas, 1776]), Burbot, and Northern Pike (Esox lucius [L, 1758]). Aside from fish, some stomachs contained pebbles or vegetation and one fish's stomach (from Tsiigehtchic) contained a mouse; however, overall, nonfish contents were extremely rare (data not shown). The absolute number of prey items in a stomach varied quite widely (data not shown). Overall Northern Pike was the most frequent prey item (53-66\%). Populations differed significantly in which prey items they had consumed $\left(\chi^{2}=2054.8\right.$, df $=9, P<0.001$, Table 3$)$. Tsiigehtchic differed significantly from Aklavik $(P=0.003)$ and Inuvik $(P=0.003)$ populations and from the Fort McPherson $(P=0.028)$ population, although this latter difference was not significant after Bonferroni correction (Table 3). The most prominent differences in consumed prey items between Tsiigehtchic and the other populations were that the Tsiigehtchic populations lacked Burbot, had few Ninespine Sticklebacks, and had a high proportion of Broad Whitefish (Figure 3). 
TABLE 3. Statistical analyses of morphological and ecological differences between populations of Burbot subspecies (Lota lota lota and L. l. maculosa) collected from four populations in the Mackenzie River Delta, Northwest Territories, Canada, using analysis of covariance (ANCOVA) with generalized linear model and $F$ or $\chi^{2}$ tests. A. Interactions between population and age, length, weight, and trophic parameters. A significant interaction indicates that populations differed in that parameter. B. Uncorrected probability values from further population pairwise comparisons indicate which populations differed from each other in the parameters identified in A as differing significantly $(P<0.001)$.

\begin{tabular}{|c|c|c|c|c|c|c|}
\hline $\bar{A}$ & Parameter & $n$ & & & $F$ value & $P$ value \\
\hline & Age & 88 & & & 3.70 & 0.0176 \\
\hline & Length & 338 & & & 10.51 & $<0.001$ \\
\hline & Weight & 338 & & & 20.37 & $<0.001$ \\
\hline & $\delta^{15} \mathrm{~N}$ & 103 & & & 7.16 & $<0.001$ \\
\hline & $\delta^{13} \mathrm{C}$ & 103 & & & 12.34 & $<0.001$ \\
\hline & Parameter & $n$ & & & $\chi^{2}$ & $P$ value \\
\hline & Stomach contents & 322 & & & 2054.8 & $<0.001$ \\
\hline \multicolumn{7}{|c|}{ Probability values } \\
\hline \multirow[t]{7}{*}{$B$} & Populations & Weight & Length & $\delta^{15} \mathbf{N}$ & $\delta^{13} \mathrm{C}$ & Stomach contents \\
\hline & FM-AK & 0.009 & $0.0003 * *$ & 0.013 & 0.864 & 0.109 \\
\hline & IN-AK & 0.129 & 0.758 & 0.113 & $<0.0001 * * *$ & 0.905 \\
\hline & TS-AK & $<0.0001 * * *$ & 0.022 & 0.176 & $0.004 *$ & $0.003 *$ \\
\hline & IN-FM & $<0.0001 * * *$ & $0.0009 * *$ & $<0.0001 * * *$ & $<0.0001 * * *$ & 0.143 \\
\hline & TS-FM & 0.031 & 0.14 & 0.217 & $0.0008 * *$ & 0.028 \\
\hline & TS-IN & $<0.0001 * * *$ & 0.047 & $0.002 *$ & 0.043 & $0.003^{*}$ \\
\hline
\end{tabular}

Note: $\mathrm{df}=$ degrees of freedom, $\mathrm{IN}=$ Inuvik, $\mathrm{AK}=$ Aklavik, $\mathrm{FM}=$ Fort McPherson, and TS $=$ Tsiigehtchic.

Note: Bonferroni corrected values at $\alpha$ of $0.05(*=P<0.0083), 0.01(* *=P<0.0017)$ or $0.001(* * *=P<0.0002)$.

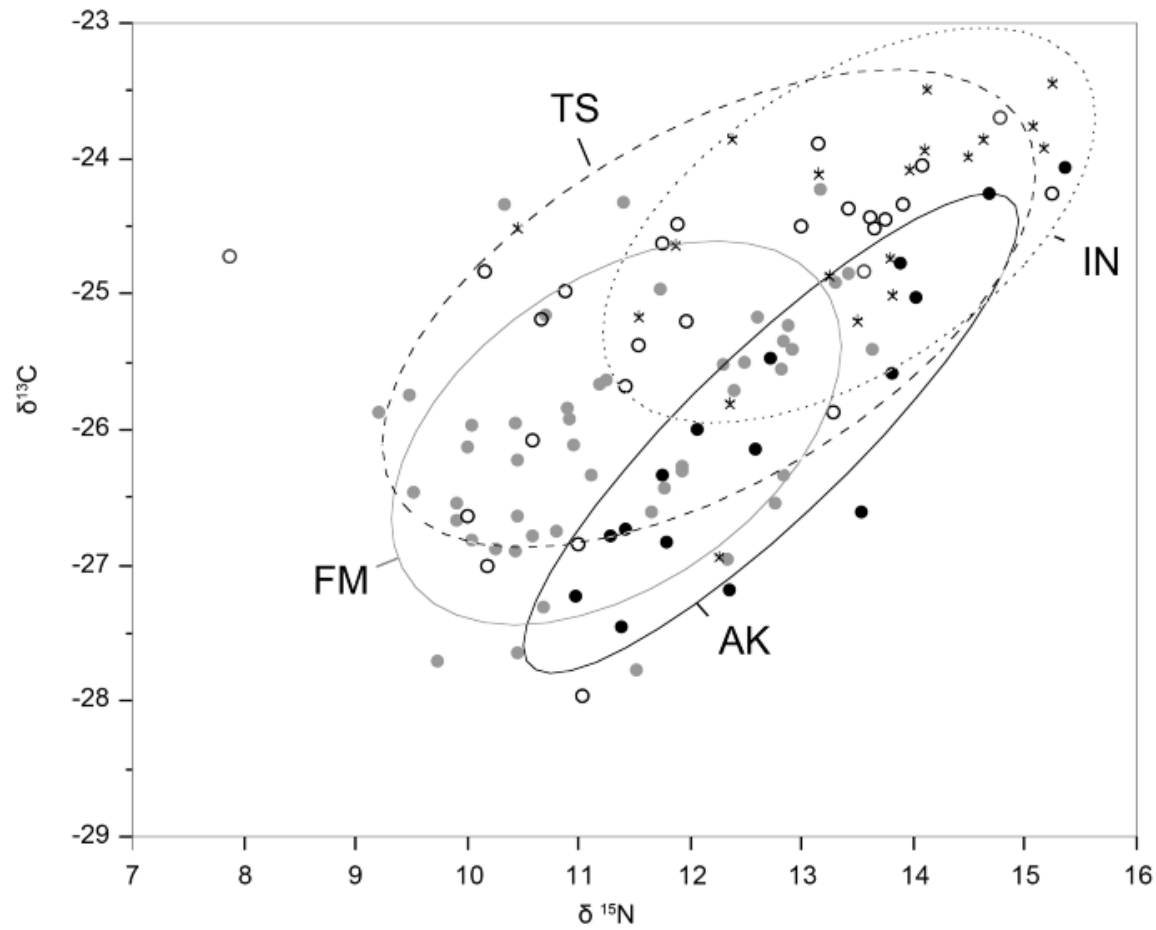

FIGURE 2. Individual carbon and nitrogen stable isotope composition of four populations of Burbot subspecies (Lota lota lota and L. l. maculosa) from the Mackenzie River Delta, Northwest Territories, Canada. Populations are circumscribed by $75 \%$ confidence ellipses: IN = Inuvik (asterisks and dotted line), AK = Aklavik (black circles and solid line), FM= Fort McPherson (grey circles and grey line), and TS = Tsiigehtchic (open circles and dashed line). 


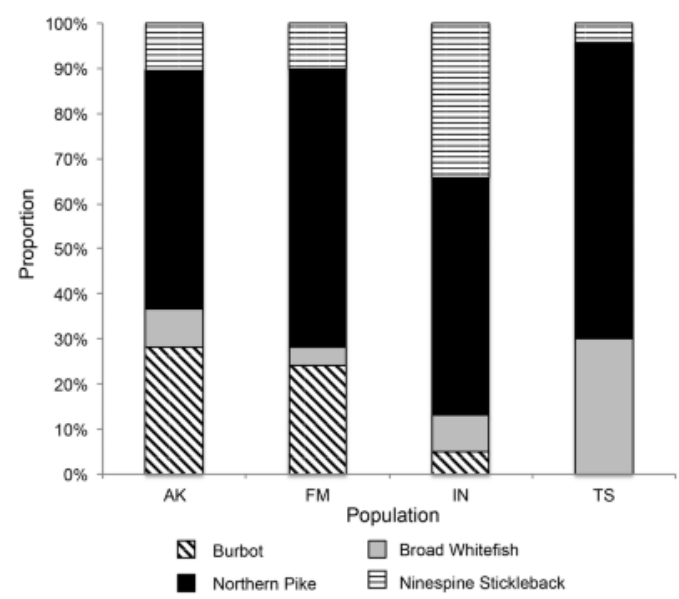

FIGURE 3. Average proportion of four main prey items found in the stomachs of four populations of Burbot subspecies (Lota lota lota and L. l. maculosa) from the Mackenzie River Delta, Northwest Territories, Canada: IN = Inuvik $(n=87), \mathrm{AK}=$ Aklavik, $(n=120), \mathrm{FM}=$ Fort McPherson $(n=105)$, and TS $=$ Tsiigehtchic $(n=10)$.

\section{Discussion}

\section{Sexual dimorphism}

We found that, consistently across populations, females had greater total length and were heavier than males. In contrast, a study by Cott et al. (2013a) found a low level of sexual dimorphism in Burbot and no differences in body size between males and females, and, in general, it has been suggested that there is little sexual dimorphism in terms of size of Burbot. In addition, we found GSI to be significantly different between females and males (means 5.66 and 11.26, respectively). In a study spanning lakes in the $L$. $l$. maculosa range across Canada, Cott et al. (2013b) also found a higher GSI among males, with GSI in both sexes at spawning time similar to our findings. Compared with other fish species, Burbot has a relatively high value of GSI, which suggests that their reproductive behaviour includes external fertilization and high communal spawning (Stockley et al. 1997; Cott et al. 2013a). This is in agreement with observations from nature that Burbot spawn in aggregations with many males surrounding one or two females and that Burbot are broadcast spawners (McPhail and Paragamian 2000). The high GSI also indicates that sperm competition may be present in Burbot males (Stockley et al. 1997; Bekkevold et al. 2002; Cott et al. 2013a). Other research has suggested that GSI in Burbot can be highly variable at spawning time (Wiggs 1974); thus, this may warrant further investigation.

\section{Morphology}

Populations varied significantly in weight and length. The sampled population from Tsiigehtchic weighed less than other populations and, on average, was also smaller in total length, although the differences were not al- ways statistically significant when controlled for age, sex, and multiple testing. Variation in Burbot morphology has been proposed to be a result of different life histories, as lotic Burbot are exposed to a different environment than lentic Burbot, and from their evolutionary history, as isolation during several cycles of glaciation has led to different genetic lineages (Fisher et al. 1996; McPhail and Paragamian 2000; Elmer et al. 2008). Therefore, the variation we found in weight and length may result from a different evolutionary history, as fish from Tsiigehtchic genetically belong to the $L$. l. maculosa lineage (Elmer et al. 2012) in contrast to the other populations, which belong to the L. l. lota lineage. Because our sampling included only one L. l. maculosa population, Tsiigehtchic, we cannot conclude that observed differences in length, weight, and diet were a result of ecological differences between the two subspecies rather than simply local interpopulation variation.

The weight-length relationship of Burbot in the Mackenzie River Delta had an intercept of -3.986 and a slope of +2.617 when all populations were combined. This relationship differed between L. l. maculosa and L. l. lota populations, consistent with differences found for each variable separately. Fisher et al. (1996) found that Burbot have a slightly different weight-length relationship, on average, across 79 populations, with an intercept of -4.868 and a slope of +2.898 , and recommended only including individuals longer than $20 \mathrm{~cm}$ because weight measurements tend to be imprecise for small fish. All individuals in our analysis were considerably longer than $20 \mathrm{~cm}$; therefore, breadth of initial sampling is not likely to explain differences between studies. Although Fisher et al. (1996) found considerable local variation in the Burbot weightlength relationship across its range, other research has found relatively little variation in size across lakes that differed in climate, productivity, or ecosystem size (Cott et al. 2013b). The extent of morphological variation may depend somewhat on environmental features, such as lentic versus lotic water bodies as well as post-glacial patterns, and deserves further research effort.

\section{Ecological variation}

Heavier isotopes are concentrated with ascent up the trophic chain, such that $\delta^{15} \mathrm{~N}$ composition is higher in carnivores than herbivores (Post 2002). We found Burbot are situated in a high trophic position as indicated by their relatively high $\delta^{15} \mathrm{~N}$. In a study conducted by Hesslein et al. (1991) in the Mackenzie River Delta, the highest trophic level was achieved by Northern Pike and Lake Trout (Salvelinus namaycush [Walbaum in Artedi, 1792]), with values of $\delta^{15} \mathrm{~N}$ of 12.3-15 in Travaillant Lake and 12-14 in Kukjuktuk Creek. Burbot were not included in that study. We found Burbot to have a mean $\delta^{15} \mathrm{~N}$ of 12.1, which is close to the level of the top predators, Lake Trout and Northern Pike, in Hesslein et al. (1991). A study investigating stable isotopes of Burbot and other piscivo- 
rous fish from water bodies close to Great Slave Lake in Canada (approximately $1400 \mathrm{~km}$ upstream from the Mackenzie River Delta) found that Burbot occupy a high trophic position, similar to Lake Trout and higher than Northern Pike and Lake Whitefish (Coregonus clupeaformis [Mitchill, 1818]) (Cott et al. 2011). Variation in $\delta^{13} \mathrm{C}$ could result from differences in abundance, interactions, and composition of organisms at lower trophic levels (primary producers and herbivores) and, therefore, provides information about the ultimate energy source of higher consumers, as the ratio changes little moving up the food chain (Zanden and Rasmussen 1999; Post 2002). Our findings place Burbot with a carbon signature similar to that found for Lake Whitefish and Broad Whitefish in previous studies (e.g., Hesslein et al. 1991).

The trophic niche inferred from stable isotope levels is also supported by our analysis of stomach contents, which consisted almost exclusively of fish prey. Other authors have noted that adult Burbot are piscivorous, with usually more than $80 \%$ of their diet consisting of fish and the remainder of macroinvertebrates and insects (Bailey 1972; McPhail and Paragamian 2000; Amundsen et al. 2003). Burbot in the Great Lakes may eat a greater variety of fish prey species (Bailey 1972; Fratt et al. 1997). In our study, stomach contents consisted almost entirely of fish and of only four species. Altogether, the stable isotope data and the stomach content analyses underline the piscivorous lifestyle of Burbot and their high trophic position in aquatic food webs.

Burbot populations differed significantly in $\delta^{15} \mathrm{~N}$ and $\delta^{13} \mathrm{C}$. We found differences in $\delta^{15} \mathrm{~N}$ between populations from Fort McPherson and Inuvik and between those from Tsiigehtchic and Inuvik, but no other populations differed. In contrast all populations differed in $\delta^{13} \mathrm{C}$ composition except for Aklavik-Fort McPherson and Tsiigehtchic-Inuvik. Values of $\delta^{15} \mathrm{~N}$ and $\delta^{13} \mathrm{C}$ are known to differ within species between different water bodies, at least partly due to variable baselines (e.g., Cott et al. 2011). However, our stomach content analyses confirm that there are at least subtle differences in ecology between populations. As in morphological analyses, Tsiigehtchic was the most divergent population and significantly differed from two of the other three populations. In contrast to other populations, Burbot from Tsiigehtchic showed no cannibalism and their stomachs contained a high proportion of Lake Whitefish.

The trophic analysis indicates complex interactions between Burbot and their resources, which differ locally, leading to variation in consumed prey and the signals of stable isotopes. It is important to note that stable isotope composition reflects a long-term (weeks or months) integration of diet, whereas stomach contents are a snapshot of the day of collection and are inherently more variable. As observed in morphological analysis, Burbot caught in Tsiigehtchic were most dif- ferent ecologically from Burbot caught in other locations, but it remains to be tested whether this difference is a result of local interspecific variation or fixed between subspecies.

Other research found that Burbot from Tsiigehtchic had fewer liver parasites than fish from Aklavik, Inuvik, or Fort McPherson (Goater 2010*). In other freshwater fish, parasite load has been found to be tightly correlated with trophic niche; pelagic fish have a higher parasite load, even within the same lake and the same species (Knudsen et al. 2013). More intensive sampling near the contact zone would be necessary to address the interesting possibility that either subspecies or localities differ in ecology or parasite susceptibility.

\section{Implications for future research}

Future research efforts should target the contact zone and its surrounding areas more intensively. Our study suggests that the Tsiigehtchic population (i.e., the only L. l. maculosa population) may differ in body length compared with all other sampled populations, which were L. l. lota. The extent to which this correlates with other morphological and ecological traits, such as trophic niche and dietary preferences, is less clear. Although we were unable to distinguish between population and subspecies differences because we sampled only one L. l. maculosa population, our study illuminates several lines of future research. From an ecological and morphological aspect, it would be interesting to identify the differences - if any exist between Burbot subspecies. From a genetic perspective, previously identified low levels of admixture at the contact zone (Elmer et al. 2012) may provide an opportunity to hone in on the genetic basis of traits that differ between subspecies through high-resolution genomic analyses (sensu Buerkle and Lexer 2008). Now that the contact zone has been rather precisely located and some key parameters of variability characterized, we suggest that this geographic, ecological, and genetic suture zone would be an excellent launch pad for evolutionary and ecological research on Burbot.

\section{Acknowledgements}

This research was funded by the Gwich'in Renewable Resource Board, Aurora Research Institute, Environment Canada's Northern Ecosystem Initiative, and Fisheries and Oceans Canada (A.A.). H.R. was funded by a Leonardo da Vinci exchange to the University of Glasgow. K.R.E. thanks R. Eckmann for advice with analyses. Thanks to Marlene Evans (Environment Canada) for organizing the stable isotope analyses, and to Dr. Cameron Goater (University of Lethbridge), Dr. Terry Dick (University of Manitoba), and Nathan Millar (Yukon Government) for advice and support throughout the project. Thanks to all the Gwich'in participants who assisted with the project (sample collection, traditional knowledge, and macro stomach analysis). 
Documents Cited (marked * in text)

Goater, C. 2010. Occurrence and pathology of liver worms in Burbot from the McKenzie River Delta. Unpublished report: University of Lethbridge, Lethbridge, Alberta, Canada.

\section{Literature Cited}

Amundsen P. A., T. Bøhn, O. A. Popova, F. J. Staldvik, Y. S. Reshetnikov, N. A. Kashulin, and A. Lukin. 2003. Ontogenetic niche shifts and resource partitioning in a subarctic piscivore fish guild. Hydrobiologia 497: 109-119.

Bailey, M. M. 1972. Age, growth, reproduction, and food of the burbot, Lota lota (Linnaeus), in southwestern Lake Superior. Transactions of the American Fisheries Society 4: 667-674.

Bekkevold, D., M. M. Hansen, and V. Loeschcke. 2002. Male reproductive competition in spawning aggregations of cod (Gadus morhua, L.). Molecular Ecology 11: 91-102.

Buerkle, C. A., and C. Lexer. 2008. Admixture as the basis for genetic mapping. Trends in Ecology \& Evolution 23: 686-694.

Cott P. A., T. A. Johnston, and J. M. Gunn. 2011. Food web position of Burbot relative to lake trout, northern pike, and lake whitefish in four sub-Arctic boreal lakes. Journal of Applied Ichthyology 27(suppl s1): 49-56.

Cott P. A., T. A. Johnston, and J. M. Gunn. 2013a. Sexual dimorphism in an under-ice spawning fish: the burbot (Lota lota). Canadian Journal of Zoology 91: 732-740.

Cott, P. A., T. A. Johnston, and J. M. Gunn. 2013b. Stability in life history characteristics among burbot populations across environmental gradients. Transactions of the American Fisheries Society 142: 1746-1756.

EImer, K. R., H. Recknagel, A. Thompson, and A. Meyer. 2012. Asymmetric admixture and morphological variability at a suture zone: parapatric burbot subspecies (Pisces) in the Mackenzie River basin, Canada. Hydrobiologia 683: 217-229.

Elmer, K. R., J. K. Van Houdt, A. Meyer, and F. A. M. Volckaert. 2008. Population genetic structure of North American burbot (Lota lota maculosa) across the Nearctic and at its contact zone with Eurasian burbot (Lota lota lota). Canadian Journal of Fisheries and Aquatic Sciences 65: 2412-2426.

Fisher, S. J., D. W. Willis, and K. L. Pope. 1996. An assessment of burbot (Lota lota) weight-length data from North American populations. Canadian Journal of Zoology 74: 570-575.

Fratt, T. W., D. W. Coble, F. Copes, and R. E. Bruesewitz. 1997. Diet of burbot in Green Bay and Western Lake Michigan with comparison to other waters. Journal of Great Lakes Research 23: 1-10.

Gwich'in Elders. 1999. Chehluk (Loche). Pages 165-170 in Gwich'in Words about the Land. Edited by G. Raygorodetsky and P. Clarkson. Gwich'in Renewable Resources Board, Inuvik, Northwest Territories, Canada.

Hesslein, R. H., M. J. Capel, D. E. Fox, and K. A. Hallard. 1991. Stable isotopes of sulfur, carbon, and nitrogen as indicators of trophic level and fish migration in the lower Mackenzie River Basin, Canada. Canadian Journal of Fisheries and Aquatic Sciences 48: 2258-2265.

Knudsen, R., A. Siwertsson, C. E. Adams, J. Newton, and P. A. Amundsen. 2014. Similar patterns of individual niche use are revealed by different time-integrated trophic tracers (stable isotopes and parasites). Ecology of Freshwater Fish 23: 259-268.

McCrimmon, H. R. 1959. Observations on spawning of burbot in Lake Simcoe, Ontario. Journal of Wildlife Management 23: 447-449.

McPhail, J. D. 1997. A review of Burbot (Lota lota) life history and habitat use in relation to compensation and improvement opportunities. Canadian Manuscript Report of Fisheries and Aquatic Sciences, 2397: viii + 37 pages.

McPhail, J. D., and C. C. Lindsey. 1970. Freshwater fishes of northwestern Canada and Alaska. Bulletin 173. Fisheries Research Board of Canada, Ottawa, Ontario, Canada. 381 pages.

McPhail, J. D., and V. L. Paragamian. 2000. Burbot biology and life history. Transactions of the American Fisheries Society 128: 11-23.

Pivnicka, K. 1970. Morphological variation in the Burbot (Lota lota) and recognition of the subspecies: a review. Journal of the Fisheries Research Board of Canada 27: 1757-1765.

Post, D. M. 2002. Using stable isotopes to estimate trophic position: models, methods, and assumptions. Ecology 83: 703-718.

Scott, W. B., and E. J. Crossman. 1973. Freshwater fishes of Canada. Fisheries Resources Board of Canada. Bulletin no. 184: 966 pages.

Slavík, O., L. Bartoš, and D. Mattas. 2005. Does stream morphology predict the home range size in Burbot? Environmental Biology of Fishes 74: 89-98.

Stockley, P., M. J. G. Gage, G. A. Parker, and A. P. Møller. 1997. Sperm competition in fishes: the evolution of testis size and ejaculate characteristics. The American Naturalist 149: 933-954.

Thompson, A. 2008. Investigation into Loche (burbot, Lota lota) biology and liver quality in the Gwich'in Settlement Area, Northwest Territories. GRRB08-01. Gwich'in Renewable Resource Board, Inuvik, Northwest Territories, Canada.

Van Houdt, J. K. J., L. de Cleyn, A. Perretti, and F. A. M. Volckaert. 2005. A mitogenic view on the evolutionary history of the Holarctic freshwater gadoid, burbot (Lota lota). Molecular Ecology 14: 2445-2457.

Wiggs, A. J. 1974. Seasonal changes in the thyroid proteinase of a teleost fish, the burbot, Lota lota L. Canadian Journal of Zoology 52: 1071-1078.

Zanden, M. J. V., and J. B. Rasmussen. 1999. Primary consumer $\delta^{13} \mathrm{C}$ and $\delta^{15} \mathrm{~N}$ and the trophic position of aquatic consumers. Ecology 80: 1395-1404.

Received 11 February 2014

Accepted 28 March 2014 